Kinestetik : Jurnal Ilmiah Pendidikan Jasmani 5 (3) (2021)

Kinestetik : Jurnal Ilmiah Pendidikan Jasmani

https://ejournal.unib.ac.id/index.php/kinestetik/index

DOI : 10.33369/jk.v5i3.16905

\title{
TEACHER'S ABILITY IN APPLYING ADAPTIVE PHYSICAL EDUCATION LEARNING TO CHILDREN WITH SPECIAL NEEDS
}

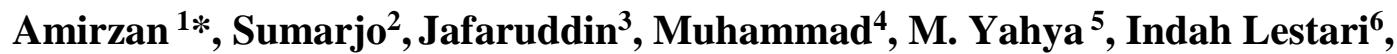 \\ ${ }^{123456}$ Physical Education Sports, Health And Recreation, Teacher Training And Education \\ Faculty, Universitas Jabal Gafur Sigli, Aceh, Indonesia
}

\section{Article Info}

Article History :

Received : July 2021

Revised : September 2021

Accepted : September 2021

Available online : September 2021

Keywords:

Teacher's Ability, Adaptive Physical Education, Children With Special Needs

\begin{abstract}
The purpose of this research is to find out. how far is the ability of PJOK teachers at SDLB Pante Raya Bener Meriah Regency in implementing adaptive physical education learning models for CSN students? The population and sample in this study were school leaders, administrative staff, permanent teachers, and honorary staff as well as 26 students of SDLB Pante Raya, the sampling technique in this study used a total sample. The data collection technique used observation, interviews, and questionnaires, while the data analysis used was data collection, data verification, and conclusion drawing. The collected data were processed using descriptive analysis of percentages. The results of this study can be concluded that PJOK teachers at SDLB Pante Raya can carry out adaptive, creative, and fun physical education learning to improve students' physical fitness and SDLB Pante Raya students like and play an active role in every PJOK learning activity carried out in schools. Thus it was answered that in general PJOK teachers understood that adaptive physical education had been implemented, but still needed to improve the ability of PJOK teachers through training/upgrading related to adaptive physical education learning, then in general respondents stated that physical fitness was needed by children with special needs to support them in the following learning at school, then they also stated that students were very fond of exercising.
\end{abstract}

\footnotetext{
Corresponding address : Jalan Gle Gapui, Universitas Jabal Gafur

ISSN 2685-6514 (Online)

Sigli, Aceh,

ISSN 2477-331X (Print)

*Corresponding email: amirzan@unigha.ac.id
} 


\section{INTRODUCTION}

Physical education as one of the subjects in schools has an important role in the development of student behavior as a whole, related to this (Pratiwi et al., 2020); (Nurhidayat, Nurhidayat, Jariono, et al., 2021) explained that: "Physical education is a process of education through physical activity. The goals achieved are thorough, encompassing the psychomotor, cognitive, and affective domains." Physical education is essentially an educational process that utilizes physical activity to produce holistic changes in individual qualities both in physical, mental, and emotional terms (Fefrian et al., 2020); (Jariono, Gatot, Nurhidayat, et al., 2021). Physical education should treat the child as a whole entity, a total being, not just regard as someone separate from his physical and mental qualities (Friskawati, 2015). Physical education, by utilizing human movement tools can make mental and moral aspects also develop (Azhari, 2013). In the implementation of physical education in schools, not only in riots for learners in general but also for learners who experience obstacles and limitations known as children with special needs.

A person with special needs does not mean "physically and spiritually unwell". A disabled person is a disabled person who can perform certain activities, but does it differently (Fefrian et al., 2020; Jariono, Sudarmanto, Kurniawan, et al., 2021; Khairun Nisa et al., 2018a, 2018b; Pratiwi et al., 2020; Ratrie Desningrum, 2007; Thompson, 2017). Children with special needs are children with special characteristics that are different from children in general without always showing mental, emotional, or physical disabilities (Jariono, 2021; Jariono, Fachezzy, Nugroho, et al., 2021) (Jariono, Gatot, Nurhidayat, et al., 2021).(Jariono, Gatot, Nurhidayat et al., 2021) Characteristics of Children with Special
Needs (CSN) include: visually impaired, deaf, mentally retarded, physically handicapped, handicapped, learning difficulties, behavior disorders, gifted children, children with health disorders (Datul Ishmi, 2021; Desiningrum, 2016; Iswari, 2007; Khairunisa Rani et al., 2018; Sambira \& Badiah, 2018; Vani et al., 2014); (Amirzan, Indra Kasih, 2019). Children with special needs have the same opportunity to have physical fitness by doing adaptive tailoring activities, namely by doing sports activities that are following the child's physical and mental condition.

In this adaptive tailoring activity, not all children with special needs will be able and willing to do so. But in supporting and providing stimulation for children to do so it is necessary to make sports modifications through the development or simplification of motion modified by PJOK teachers to meet sports activities in children with special needs. So in this case it is required that the special ability of PJOK teachers concoct a sports activity that is easy, lively, and interesting for the child so that they are willing to do sports activities. Therefore, in the Extraordinary School the implementation of adaptive physical learning is very necessary, because, with this adaptive physical, students with special needs can further improve their motor skills. This adaptive physical existence is very important especially for sports teachers who teach (Choirullita et al., 2020). It takes an understanding of the conditions and needs of students with special needs to develop the abilities and potential possessed by students with special needs.

With good physical freshness, students will be excited in teaching and learning activities carried out in school because physical freshness is a determining factor for the child in supporting every activity he does every day. If their physical freshness is disturbed, then all physical and 
psychological effects of the child will be disturbed, so he is reluctant in various activities, all of which will interfere with the growth and development of students who need special needs. This nature is very necessary a breakthrough effort for PJOK teachers in special needs schools to try to create a sports learning that is in demand, but whether PJOK teachers have modified a construct of adaptive learning models based on the needs and needs of students' physical conditions. To that end, researchers will examine and examine to find out in the field how the efforts that have been made by PJOK teachers so far in schools whose students have special needs activate their students in exercising to increase the physical freshness of students.

\section{METHODS}

Descriptive research methods using quantitative research approaches consist of observations, interviews, questionnaires, and documentation to reinforce the results of these studies. Research Time and place conducted at SDLB Pante Raya Bener Meriah Aceh regency on April 1- 20, 2021, the target of this research is SDLB Pante Raya Aceh

\section{Participants}

The sample in this study was the principal and deputy, education personnel as well as the entire board of teachers and honorees at SDLB Pante Raya Bener Meriah Aceh Regency as many as 26 people.

\section{Sampling Procedures}

Data retrieval procedures through documentation, interviews, and questionnaires, this research instrument uses teacher understanding questionnaires related to the implementation of adaptive tailor learning consisting of teachers as a companion, motivator, innovator, limiting tasks in learning, guaranteeing the quality of effective and efficient learning and teachers understand the characteristics of learners.

\section{Materials and Apparatus}

Data collection techniques are carried out in four techniques, namely observation, interview, questionnaire, and documentation. Observations are made to check directly the condition of the subject at the research site. Observations were made adjusting the conditions at SDLB Pante Raya Bener Meriah Aceh Regency. Interviews are conducted to obtain information related to teacher understanding related to the implementation of adaptive learning. The questionnaire is used to obtain quantitative data consisting of teachers as escorts, motivators, innovators, limiting tasks in learning, ensuring the quality of effective and efficient learning and teachers understand the characteristics of learners while documentation related to photos or records of learning situations in SDLB Pante Raya Bener Meriah Aceh Regency.

\section{Procedures}

This study consists of several steps of research, namely: (i) Researchers conducted observations at SDLB Pante Raya Bener Meriah Aceh Regency to obtain a direct picture related to the condition of the subject as research material; (ii) Compile an interview instrument that has been validated by an expert consisting of special needs child experts; and (iii) Next do triangulate data done for validity check to strengthen from the interview results data.

\section{Design or Data Analysis}

Data analysis techniques use data reduction, data verification, and conclusion withdrawal as a whole data analysis using frequency descriptive analysis with the help of Excel 2019 


\section{RESULTS}

Characteristics of respondents

Respondents in this study consisted of the principal and deputy principal, education personnel as well as the entire board of teachers and honorees. Interestingly, there are more female educators compared to male educators in SDLB Pante Raya Aceh. For more details, you can see the following histogram:

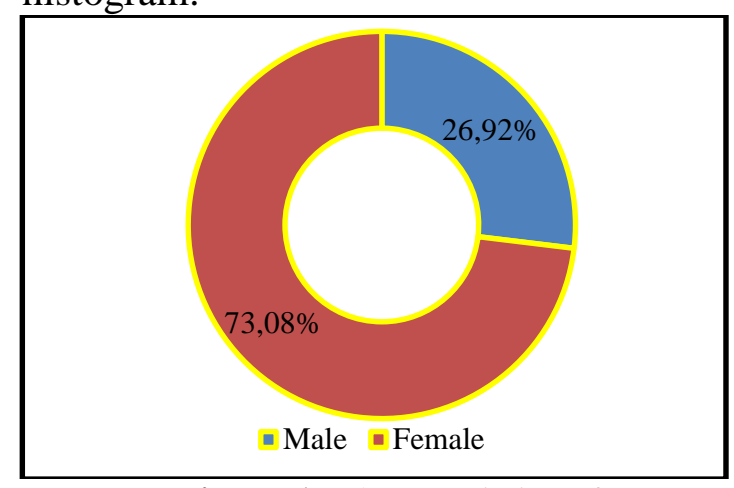

\section{Figure 1. Characteristics of respondents}

Gender characteristics of respondents about the teacher's ability to apply tailor learning in children with special needs indicate that more female respondents in applying adaptive tailor learning. Among 26 respondents, $73.08 \%$ were female and $26.92 \%$ were male.

\section{Long Teaching}

Long teaching of respondents was diverse, almost half(53). $85 \%$ ) of participants have spent more than 15 years teaching, $15.38 \%$ of they have spent between 5 and 10 years, and 23years. 08 of them spent time teaching him over 15 years. Interestingly, only $7.69 \%$ spent between one and five years teaching at SDLB Pante Raya Aceh. 


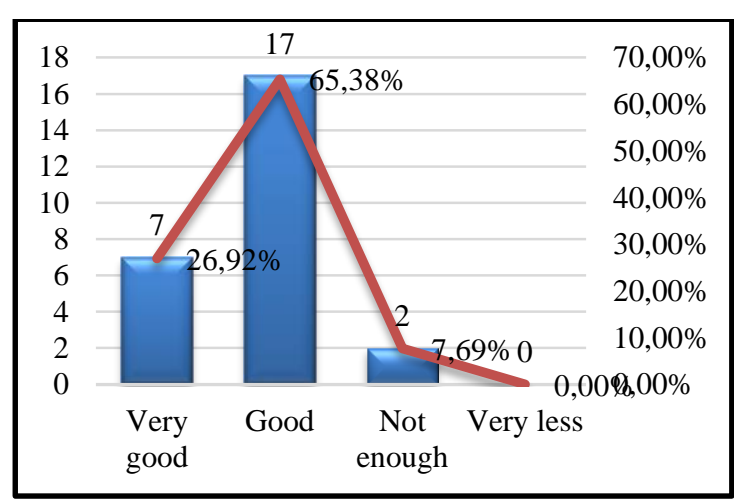

Figure 3. Teachers in applying adaptive learning

Figure 3 shows that teachers in applying adaptive physical education learning to children with special needs in SDLB Pante Raya Aceh in the good category. This is evidenced following descriptive analysis of the frequency of leveling categories both obtained the highest score of $65.88 \%$ and very well by $26.92 \%$. uniqueness in this study statement is very less by $7.69 \%$, likely, the teacher is still new in the teaching process in the face of children with special needs.

\section{DISCUSSION}

physical education learning to children with special needs in SDLB Pante Raya Aceh in the good category. This is in line with the results of research conducted by (Haris \&, Johandri Taufan, 2019) that the role of sports teachers in developing adaptive PJOK is very large because the ability and mastery of materials owned by sports teachers can help students with special needs in their learning, in addition, sports teachers also play a role in improving motor and movement of students with special needs. This research is strengthened by the results of the study (Friskawati, 2015; Pambudi et al., 2019; Typhoon et al., 2019; Vai \& Lorenza, 2019; Widiyanto et al., 2021) that the role of adaptive physical education in realizing educational goals for children with needs has a major contribution. Adaptive physical education is intended to provide opportunities to participate in children who have disorders that are applied in certain schools. The results of the study are supported by the results of research (Hastata et al., 2019) the physical education management system in schools still has many weaknesses. There are only a few schools that have ever planned management in the implementation of adaptive physical education. Adaptive Physical Education in the school is not yet on target and optimal related to the service to children with special needs. The use of infrastructure facilities is still not modified following the needs of children who are taught. Teaching materials have not been adapted to the child's disability.

The results of this study are an analysis of the ability of teachers in applying adaptive physical education which is currently studying the ability of teachers in applying adaptive physical education learning is not much. The existence of the results of this study can be a reference for Extraordinary Schools to provide a role for teachers in developing adaptive physical education because the teachers can further increase the role of participation of learners in participating in sports activities.

Based on the results of this study, it can be argued that the ability of teachers in teaching children with special needs is determined by several factors, one of which is the teacher as a companion, motivator, innovator, limiting tasks in learning, ensuring the quality of effective and efficient learning and teachers understand the characteristics of learners and psychological factors, one of which is teaching motivation so it needs to be developed effectively. optimal to achieve optimal appearance. 


\section{CONCLUSION}

This research can be concluded that the ability of teachers in applying adaptive learning in good theory consists of teacher indicators as a companion, motivator, innovator, limiting tasks in learning, ensuring the quality of effective and efficient learning and teachers understand the characteristics of learners. The results of this study also contribute to expanding the latest knowledge about the ability of teachers in applying adaptive learning to children with special needs through synergy between principals and representatives, education personnel, and the entire board of teachers and honorees. Given that this study involved only a small sample, caution needs to be exercised to apply more effective and efficient adaptive tailoring learning to CSN. However, further research is needed to apply adaptive learning to children with special needs taking into account social, psychosocial environmental variables, applying modified learning, and those related to problems in the application of adaptive tailoring learning in children with special needs.

\section{ACKNOWLEDGEMENT}

Thank you to the Faculty of Teacher Training and Education, Jabal Gafur University who has fully facilitated researchers to conduct research. Furthermore, the researcher thanked the principal and deputy, education personnel, and the entire board of teachers and honorees at SDLB Pante Raya Bener Meriah Aceh Regency To Help The Research Process Until The End Of the study.

\section{REFERENCES}

Amirzan, Indra Kasih, M. Y. (2019). Pemahaman Guru Pjok Tentang
Pengaruh Kesiapan Mental Terhadap Pencapaian Prestasi Olahraga. Unimed.Ac.Id, 3(2), 98-104.

Azhari, H. (2013). Pelaksanaan Pembelajaran Pendidikan Jasmani Kesehatan Dan Olahraga. Persepsi Masyarakat Terhadap Perawatan Ortodontik Yang Dilakukan Oleh Pihak Non Profesional, 53(9), 16891699.

Choirullita, A. M., Setiawan, W., \& Irawan, L. (2020). Keterlaksanaan Pembelajaran Penjas Pada Siswa SDLB di Probolinggo Tahun 2020. SPRINTER: Jurnal Ilmu Olahraga, 1(2), 97-101.

Datul Ishmi. (2021). Pelaksanaan Pembelajaran Pendidikan Agama Islam Bagi Anak Berkebutuhan Khusus Tunagrahita di Masa Pandemi Covid-19. WARAQAT : Jurnal IlmuIlmu Keislaman, 6(1), 12-23. https://doi.org/10.51590/waraqat.v6i1 .128

Desiningrum, D. R. (2016). Psiokologi Anak Berkebutuhan Khusus. Psikosain.

Fefrian, Y., Mardhika, R., RH, S., \& Sumardi, S. (2020). Penjas Adaptif Bagi Guru Sekolah Luar Biasa (SLB) Siswa Budhi Surabaya. SPEED Journal : Journal of Special Education, 3(2), 101-106. https://doi.org/10.31537/speed.v3i2.2 88

Friskawati. (2015). Implementasi pembelajaran penjas berbasis masalah gerak pada siswa tunarungu. Jurnal Pendidikan Unsika, 3(1), 79-96.

Haris, F., \& , Johandri Taufan, S. N. (2019). Peran Guru Olahraga bagi Perkembangan Pendidikan Jasmani Adaptif di Sekolah Luar Biasa. Jurnal Basicedu, 1(1), 1-9. https://doi.org/https://doi.org/10.3100 4/basicedu.v5i5.1469 ISSN

Hastata, L. T., Sugiyanto, \& Hidayatullah, M. F. (2019). Pendidikan Jasmani 
Adaptif Anak Berkebutuhan Khusus Di Kabupaten Boyolali. Proceedings of the National Seminar on Women's Gait in Sports towards a Healthy Lifestyle 27 April 2019 Universitas Tunas Pembangunan Surakarta Indonesia, April, 1-23.

Jariono, Gatot, Nurhidayat, N., Sudarmanto, E., Kurniawan, A. T., \& Triadi, C. (2021). Pendampingan dan Pelatihan Peran Guru Dalam Mengurangi Perilaku Hiperaktif Anak Berkebutuhan Khusus di SLB Negeri Sukoharjo. Panrannuangku Jurnal Pengabdian Masyarakat, 1(1), 37-43. https://doi.org/https://doi.org/10.3587 7/panrannuangku478

Jariono, G. (2021). Strategies to Teach Children with Special Needs Amid COVID-19 Pandemic. Linguistics and Culture Review, 5(July), 633-641. https://doi.org/https://doi.org/10.3702 8/lingcure.v5nS1.1448

Jariono, G., Fachezzy, F., Nugroho, H., Maslikah, U., Nurhidayat, N., Sudarmanto, E., Triadi, C. (2021). Management Strategy for Hyperactive Behavior for Children with Special Needs Viewed from the Perspective of Teacher and Parents. Linguistica Antverpiensia, 3. https://hivt.be/linguistica/article/view $/ 1735$

Jariono, G., Sudarmanto, E., Kurniawan, A. T., Triadi, C., \& Anisa, M. N. (2021). Pendampingan Pelatihan Kemampuan Motorik Anak Berkebutuhan Khusus Melalui Latihan High Intensity Interval Training. Indonesian Journal of Engagement, Community Services, Empowerment and Development, 1(2), 81-90. https://doi.org/https://doi.org/10.5306 7/ijecsed

Khairun Nisa, Mambela, S., \& Badiah, L. I. (2018a). Karakteristik Dan Kebutuhan Anak Berkebutuhan
Khusus. Jurnal Abadimas Adi Buana, 2(1), $33-40$ https://doi.org/10.36456/abadimas.v2 .i1.a1632

Khairun Nisa, Mambela, S., \& Badiah, L. I. (2018b). Karakteristik Dan Kebutuhan Anak Berkebutuhan Khusus. Jurnal Abadimas Adi Buana. https://doi.org/10.36456/abadimas.v2 .i1.a1632

Khairunisa Rani, Rafikayati, A., \& Jauhari, M. N. (2018). Keterlibatan Orangtua Dalam Penanganan Anak Berkebutuhan Khusus. Jurnal Abadimas Adi Buana. https://doi.org/10.36456/abadimas.v2 .i1.a1636

Nurhidayat, Nurhidayat, Jariono, G., Sudarmanto, E., \& Kurniawan, A. T. (2021). Teacher Strategy In Reducing Hyperactive Behavior Of Children With Special Needs During Pandemic Covid-19 At SLBN Sukoharjo. International Journal of Economy, Education and Entrepreneuship, 1(1), 79-86.

https://doi.org/https://doi.org/10.5306 7/ije3.v1i1

Pambudi, M. I., Winarno, M., \& Dwiyogo, W. D. (2019). Perencanaan dan Pelaksanaan Pembelajaran Pendidikan Jasmani Olahraga Kesehatan. Jurnal Pendidikan Olahraga, Universitas Negeri Malang, 4(1), 110-116. http://journal.um.ac.id/index.php/jptp $\mathrm{p} /$

Pratiwi, F., Kalalo, C. N., \& Syamsudin. (2020). Pembelajaran Pendidikan Jasmani Adaptif di SD Luar Biasa Negeri Anim-Ha Merauke. Musamus Journal of Physical Education and Sport, $\quad$ 03(01), 31-34. https://doi.org/10.35724/mjpes.v

Sambira, \& Badiah, L. I. (2018). Karakteristik dan Kebutuhan Anak Berkebutuhan Khusus. Karakteristik Dan Kebutuhan Anak Berkebutuhan 
Khusus.

Taufan, J., Fitri, R., \& Rafmateti, R. (2019). Implementasi Pembelajaran Pendidikan Jasmani Adaptif bagi Siswa Tunarungu di SLB Negeri 2 Padang Melalui Penugasan Dosen di Sekolah. Jurnal Pendidikan Kebutuhan Khusus, 3(2), 31. https://doi.org/10.24036/jpkk.v3i2.54 6

Thompson, J. (2017). Memahami Anak Berkebutuhan Khusus. In Jurnal Administrasi Pendidikan Realita Volume 15, No. 2 Tahun 2017.

Vai, A., \& Lorenza, J. (2019). Implementasi Pembelajaran Penjas Adaptif Pada Anak-Anak Kebutuhan Khusus Di Sekolah Dasar Inklusif. Altius: Jurnal Ilmu Olahraga Dan Kesehatan, 8(1), 9-14. https://doi.org/10.36706/altius.v8i1.8 243

Vani, G. C., Raharjo, S. T., Hidayat, E. N., \& Humaedi, S. (2014). Pengasuhan (Good Parenting) Bagi Anak Dengan Disabilitas. Share: Social Work Journal. https://doi.org/10.24198/share.v4i2.1 3067

Widiyanto, W. E., Galuh, E., \& Putra, P. (2021). Pendidikan jasmani adaptif di sekolah inklusif bagi anak berkebutuhan khusus. Sport Science \& Education Journal, 2(2), 28-35. https://ejurnal.teknokrat.ac.id/index.p $\mathrm{hp} /$ sport/issue/archive $\% 250$ 